\title{
The Ichthyoplankton State \\ in the Sevastopol Bay Mouth (Black Sea)
}

Tatyana N. Klimova*, Irina V. Vdodovich, Sergei M. Ignatiev, Sergei A. Seregin, Natalia S. Kuzminova, Natalia I. Pustovarova and Elena V. Popova A.O. Kovalevsky Institute of Marine Biological Research RAS 2 Nakhimov, Sevastopol, 299011, Russia

Received 12.12.2016, received in revised form 24.01.2017, accepted 28.02.2017

Data on abundance dynamics, species diversity, and trophic relationships of ichthyoplankton in the Sevastopol Bay during 2002-2014 are presented. In the period of 2009-2014 the tendency of an increase of indexes of species diversity and species richness were observed in comparison with the last decade of XX century. Increased copepod abundance, including invasive Oithona davisae, is assumed to be the reason for increased survival rate of larvae and rising number of commercial fish species, which migrate to this area for spawning and growing.

Keywords: Black Sea, ichthyoplankton, abundance, species diversity, fish larvae feeding, microzooplankton. 


\title{
Состояние ихтиопланктона в устьевой части Севастопольской бухты (Черное море)
}

\author{
Т.Н. Климова, И.В. Вдодович, \\ С.М. Игнатьев, С.А. Серегин, \\ Н.С. Кузьминова, Н.И. Пустоварова, Е.В. Попова \\ Институт морских биологических исследований \\ имени А.О. Ковалевского РАН \\ Россия, 299011, Севастополь, пр. Нахимова, 2
}

\begin{abstract}
По результатам комплексных мониторинговых исследований 2002-2014 г2. представлена динамика численности, видового разнообразия и трофических взаимоотномений ихтиопланктона на примере устьевой части Севастопольской бухты. В 2009-2014 г2. по сравнению с последним десятилетием $X X$ в. в ихтиопланктонном комплексе отмечена тенденция к увеличению показателей индексов видового разнообразия, видового богатства и выровненности. Возростая численность рачкового зоопланктона, в том числе копеподывселениа Oithona davisae, способствовала повымению выживаемости личинок рыб и увеличению численности промысловых пелагофильных видов рыб, мигрирующих в район исследований на нерест и нагул.
\end{abstract}

Ключевые слова: Черное море, ихтиопланктон, численность, видовое разнообразие, питание личинок рыб, микрозоопланктон.

\section{Введение}

Численность ихтиопланктона и его распределение зависят от состояния планктонного сообщества, а видовой состав - от состава ихтиофауны. В начале XX в. С.А. Зернов (1913), анализируя уловы рыбаков в районе Севастополя, описал 61 вид рыб из 40 семейств без учета многочисленных видов сем. Gobiidae. В 1930-е гг. здесь достоверно размножались 40 видов рыб (Водяницкий, 1936). В 1950-х г. Л.А. Дука (1959) только в устьевой части Севастопольской бухты идентифицировала икру и личинок 34 видов рыб. Ограничение водообмена Севастопольской бухты с открытым морем в конце 70-х г. $\mathrm{XX}$ в. уже через 10 лет привело к снижению числа видов ихтиопланктона почти вдвое (Ихтиофауна черноморских бухт..., 1993). В конце 1980-х гг. в результате увеличения антропогенной нагрузки в экосистеме Черного моря происходили негативные изменения на всех трофических уровнях (Замбриборщ, 1985; Зайцев, 1992; Золотарев, 1994; Игнатьев и др., 2001; Pacc, 2001; Gucu, 2002). Эвтрофикация шельфовых вод и исчезновение хищников привели к увеличению численности мелких короткоцикловых планктоноядных рыб (Замбриборщ, 1985; Зайцев, 1992; Pacc, 2001) и вспышке обилия желетелого макропланктона, в том числе и вселенцагребневика Mnemiopsis leidyi A. Agassiz, 1865 (Игнатьев и др., 2001; Gucu, 2002; Финенко и др., 2006). Появились и новые, ранее не описанные виды; в период с 1981 по 2011 г. в Севастопольской бухте отмечено 67 видов рыб (Болтачев, Карпова, 2012). В 1990 г. в устье- 
вой части Севастопольской бухты в ихтиопланктоне встречалось всего 13 видов икры и личинок рыб; вероятно, к этому привела возросшая численность желетелого макропланктона (Климова, 2005). Положительные тенденции к восстановлению видового состава и численности ихтиопланктона стали наблюдаться только после 2000 г. (Климова, 2005; Климова, Вдодович, 2011).

Цель данной работы - на основании анализа многолетних мониторинговых исследований макро-, микро-, ихтиопланктона и взрослых рыб дать сравнительную оценку изменений, произошедших в численности, видовом разнообразии и трофических взаимоотношениях ихтиопланктонного комплекса устьевой части Севастопольской бухты в период 2002-2014 гг.

\section{Характеристика}

\section{района исследований}

Севастопольская бухта представляет собой частично замкнутый водоем эстуарного типа (Ихтиофауна черноморских бухт..., 1993; Акватория и берега..., 1999; Гордина и др., 2003; Куфтаркова и др., 2007). Температура поверхностного слоя воды в устьевой части Севастопольской бухты колеблется в течение сезона с максимальным значением $27{ }^{\circ} \mathrm{C}$ в июле-августе и минимальным $6{ }^{\circ} \mathrm{C}$ - в феврале-марте. В связи с малыми глубинами сезонный термоклин слабо выражен, разность значений температур у дна и поверхности летом составляет $3-7{ }^{\circ} \mathrm{C}$, а зимой $-1-1,5{ }^{\circ} \mathrm{C}$. Соленость у дна колеблется от 17,5 до $18,5 \%$, с минимальными значениями в весенне-летний сезон. В поверхностном слое соленость меняется от 16,7 до $17,0 \%$ и зависит от активности водообмена и объема речного стока. Интенсивность водообмена в бухте определяется в основном сгонно-нагонными явлениями. Приток бо- лее соленой воды, изрезанность береговой линии и трансформация опресненной воды из Черной речки по оси бухты с востока на запад формируют устойчивые вихревые образования по обе стороны выхода из бухты. В годы с низким и умеренным уровнем осадков в осенне-зимний период наблюдается увеличение уровня морской воды за пределами бухты, что может привести к преобладанию адвекции морской воды над выносом трансформированных речных вод. Среднее значение солености поверхностного слоя бухты в такие годы достигает 17,5\%. Содержание кислорода у поверхности колеблется от 77 до $120 \%$, а у дна - от 93 до $123 \%$, такие высокие показатели характерны для прибрежных акваторий моря. Наиболее благоприятная гидролого-гидрохимическая ситуация для выживания ихтиопланктона в Севастопольской бухте складывается в период адвекции морских вод при преобладании сгонно-нагонных ветров северного, северовосточного и восточного направлений (Гордина и др., 2003; Куфтаркова и др., 2007).

\section{Материалы и методы}

Сбор ихтиопланктона и желетелого макропланктона осуществляли сетью Богорова-Расса (БР-80/113, ячея 400 мкм, площадь входного отверстия 0,5 $\mathrm{M}^{2}$ ) в режиме горизонтального 5-минутного поверхностного лова и вертикального лова 0-10 м. Ихтиопланктон фиксировался 4\%-ным раствором формальдегида и обрабатывался в лабораторных условиях под бинокулярным микроскопом (МБС-10) в течение недели после сбора. Изучение питания личинок проводилось по методике (Дука, Синюкова, 1976). Идентификацию потребленных пищевых объектов проводили по «Определителю фауны Чёрного и Азовского морей» (1969). По морфологическим показателям 
и особенностям питания личинки рыб распределены по размерным группам: 1-я группа - желточное питание; 2-я группа - смешанный тип питания; 3-я группа - внешнее питание; 4-я группа - питание крупными формами зоопланктона (Размножение и экология массовых рыб..., 1970). Восстановленный вес потребленных пищевых организмов рассчитан по (Петипа, 1957). Соотношение количества и массы кормовых объектов в пищевом комке выражено в процентах, индексы потребления - в продецимиллях (\%о). Взрослых рыб отлавливали донными ловушками (СБ-3) с ячеей 12 мм и обрабатывали в лабораторных условиях без фиксации сразу после вылова (Правдин, 1966). Желетелый макропланктон обрабатывали в свежем виде: сразу после отлова измеряли диаметр купола у медуз и длину тела без лопастей - у гребневиков. Для расчета сырой массы использовали уравнения зависимости массы от длины (Аболмасова и др., 2012). Пробы метазойного микрозоопланктона отбирали в поверхностном слое воды с последующей подготовкой и обработкой (Серегин, Попова, 2012). Взрослые рыбы определялись по (Васильева, 2007), ихтиопланктон - по (Дехник, 1973), видовые названия гидробионтов даны по http://www.marinespecies.org/index. php. Средняя численность организмов (экз/ м $^{2}$ ) и индексы разнообразия (Одум, 1986) рассчитаны по данным вертикальных ловов. Поскольку прибрежные воды районов мыса Толстый и Карантинной бухты беспрепятственно направляются в Севастопольскую бухту, видовой состав и численность взрослых рыб и ихтиопланктона в устьевой части Севастопольской бухты мы рассматривали с учетом материалов из других бухт: Карантинной, Александровской и Мартыновой и прибрежных станций у мыса Толстый (Ихтиофауна черноморских бухт..., 1993).

\section{Результаты и обсуждение}

С 2002 по 2014 г. в районе устьевой части Севастопольской бухты было идентифицировано 72 вида рыб из 33 семейств, в том числе 60 видов взрослых рыб из 28 семейств и 49 видов икры и личинок рыб из 28 семейств. В 1988-1990 гг. в районе устьевой части Севастопольской бухты было идентифицировано всего 40 видов рыб из 24 семейств, в том числе икра и личинки 24 видов из 18 семейств и взрослые рыбы 28 видов из 19 семейств (Ихтиофауна черноморских бухт..., 1993; Климова, 2005). Коэффициент видового сходства взрослых рыб с ихтиопланктоном тогда составлял 0,43. В 2003-2004 гг. в устьевой части Севастопольской бухты было отмечено 63 вида рыб из 28 семейств, в том числе взрослых рыб 55 видов из 26 семейств и 36 видов икры и личинок рыб из 22 семейств (Климова, 2005; Салехова и др., 2007). Коэффициент видового сходства ихтиопланктона и взрослых рыб несколько увеличился - до 0,62. В 2009-2014 гг. в Севастопольской бухте было идентифицировано 56 видов рыб, в том числе взрослых - 39 видов из 25 семейств и 42 вида икры и личинок рыб из 26 семейств. Видовой состав ихтиопланктона расширился за счет появления ранее отсутствующих в этом районе исследований троепера Tripterygion tripteronotum (Risso, 1810), носатого губана Symphodus rostratus (Bloch, 1791), бопса Sparus boops Linnaeus, 1758, ласточки Chromis chromis (Linnaeus, 1758), пиленгаса Liza haematocheila (Temminck et Schlegel, 1845) и бычка пятнистого Pomatoschistus pictus (Malm, 1865) (Климова, Вдодович, 2011). Индекс видового сходства состава взрослых рыб с ихтиопланктоном не изменился по сравнению с 2003-2004 гг.

Используя новые и опубликованные данные (Климова, 2005; Климова, Вдодович, 2011), рассмотрим динамику среднегодовой численности и количества видов в ихтиоплан- 


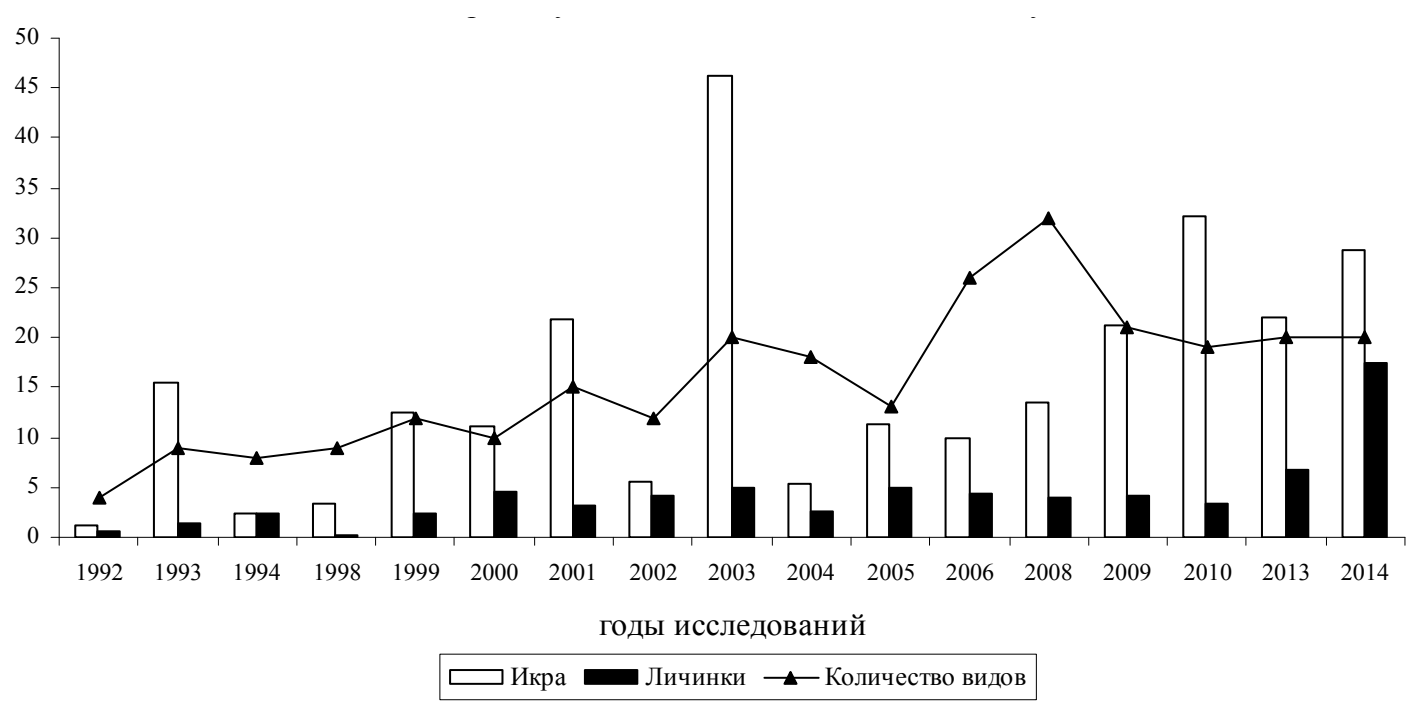

Рис. 1. Динамика количества идентифицированных видов и среднегодовой численности (экз/м²) икры и личинок рыб в устьевой части Севастопольской бухты в период с 1990 по 2014 г.

ктоне по данным вертикальных ловов в период с 1990 по 2014 г. (рис. 1). В 1990-е гг. низкая численность личинок рыб была обусловлена в первую очередь снижением обилия кормового зоопланктона (Ихтиофауна черноморских бухт..., 1993). Если в 1955-1965 гг. пищевой спектр бычков и собачек включал до 34 видов кормовых организмов, то в 1989-1990 гг. он не превышал 10 видов, в основном 3-7, и в августе-сентябре доля личинок с пустыми кишечниками в среднем составляла 64-74 \% (Ихтиофауна черноморских бухт.., 1993). Ухудшение условий питания личинок рыб произошло в результате резкого увеличения с 1970-х гг. биомассы желетелого макропланктона, повлиявшей на видовую структуру и численность планктона (Зайцев, 1992). В конце 70-х - начале 80-х гг. ХХ в. в районе наблюдалось вспышкообразное увеличение численности и биомассы аборигенной медузы Aurelia aurita (Linnaeus, 1758). К моменту проникновения и развития гребневика Mnemiosis leidyi (1982-1985 гг.) биомасса A. aurita достигала максимального значения и была на поря- док выше, чем в 1960 - 70-е гг. (Зайцев, 1992). Основными факторами резкого увеличения биомассы желетелого макропланктона, включая и массовое развитие $M$. leidyi, вероятно, были эвтрофикация шельфовых вод и увеличение промысла массовых короткоцикловых пелагических видов рыб. Увеличение численности кормового планктона в отсутствие видов рыб-конкурентов в питании, привело к вспышке численности желетелого макропланктона (Зайцев, 1992; Рacc, 2001; Gucu, 2002; Климова, 2005; Shiganova et al., 2014; Stefonova, 2014).

В начале 1990-х гг. A. aurita сменил гребневик-вселенец M. leidyi, биомасса которого закономерно нарастала, пока в 19941995 гг. не достигла максимальных значений (Игнатьев и др., 2001). В этот период для его популяции было характерно наличие максимума обилия осенью при наиболее интенсивном размножении в июне-августе. В прибрежных районах фактически сформировалось новое мезозоопланктонное сообщество, которое отличалось крайней бедностью видового со- 
става и низкой численностью. С появлением в 1999 г. нового гребневика-вселенеца Beroe ovata Bruguière, 1789 в экосистеме появился хищник, потребляющий M. leidyi и способный в значительной степени снижать размеры его популяции (Shiganova et al., 2001). M. leidyi встречался в районе исследования практически круглогодично в отличие от B. ovata, присутствие которого было ограничено примерно полугодом. Перезимовавшая популяция $M$. leidyi, не особенно многочисленная, состояла из крупноразмерных особей, начинающих размножение в апреле. Численность вида резко увеличивалась только в июле, когда в уловах доминировали мелкие особи нового поколения. Появление B. ovata быстро снижало обилие M. leidyi приблизительно на порядок (сентябрь) до его почти полного исчезновения (октябрь). Практически полностью истребив популяцию жертвы, берое прекращал размножение, численность и биомасса его постепенно сокращались, вплоть до полного исчезновения в декабре. Снижение численности M. leidyi вело к увеличению численности и разнообразия видов как мезопланктона (в состав которого входит и ихтиопланктон), так и микрозоопланктона - кормовой базы личинок и молоди рыб. Позднее появление берое и его невысокое обилие в «холодные» 2003-2004 гг. обусловили сохранение мнемиопсисом высокой численности (Финенко и др., 2006), что привело к снижению численности личинок рыб. Увеличение численности личинок теплолюбивых видов рыб началось только с 2005 г., однако вплоть до 2009 г. в видовой структуре личинок преобладали непромысловые виды из сем. бычковых и собачковых, а средняя численность личинок за летний сезон не превышала 7 экз $/ \mathrm{M}^{2}$ (рис. 1).

С конца 2009 г. численность метазойного микрозоопланктона в устьевой части Севастопольской бухты была стабильно вы- сокой. Его основу (чаще всего более 80 \%) на протяжении всего годового цикла составляли науплиальные и копеподитные стадии веслоногих ракообразных. В летний период преимущественно преобладали ювенильные стадии копеподы-вселенца Oithona davisae Ferrari F.D. et Orsi, 1984 (Серегин, Попова, 2012). Наличие высокой концентрации науплиальных стадий копепод является решающим фактором для выживания личинок рыб из пелагической икры, что обусловлено их постэмбриональным развитием. Из пелагических икринок обычно выклевываются пассивные, слаборазвитые личинки, в то время как личинки, выклюнувшиеся из донной икры, обычно хорошо сформированы и сразу же после выклева переходят к активному образу жизни (Дехник, 1971). Вероятно, переход личинок из пелагической икры с желточного на смешанный тип питания во многом зависит от концентрации и доступности ювенильных стадий копепод.

В 2009 г. впервые с 1990-х гг. доля личинок пелагофильных промысловых видов возросла до $22 \%$. С 2010 г. в кишечниках личинок рыб как из пелагической, так и из демерсальной икры наблюдается значительное увеличение количества потребленных пищевых организмов. В 2002 г. в кишечниках личинок рыб фиксировали в среднем 1-2 экз. пищевых объектов, а в 2014 г. - в среднем 6-8 экз., максимальное значение этого параметра. Увеличение количества пищевых объектов в кишечниках личинок обусловило возрастание индекса потребления пищи. Особенно наглядно это прослеживается у личинок промысловых видов рыб из семейств Engraulidae, Carangidae, Sparidae и Mullidae (рис. 2). С 2002 по 2014 г. индекс потребления пищи у личинок промысловых видов рыб возрос в 20 раз (рис. 2). Отмечено увеличение доли личинок старших возрастных групп, перешедших 


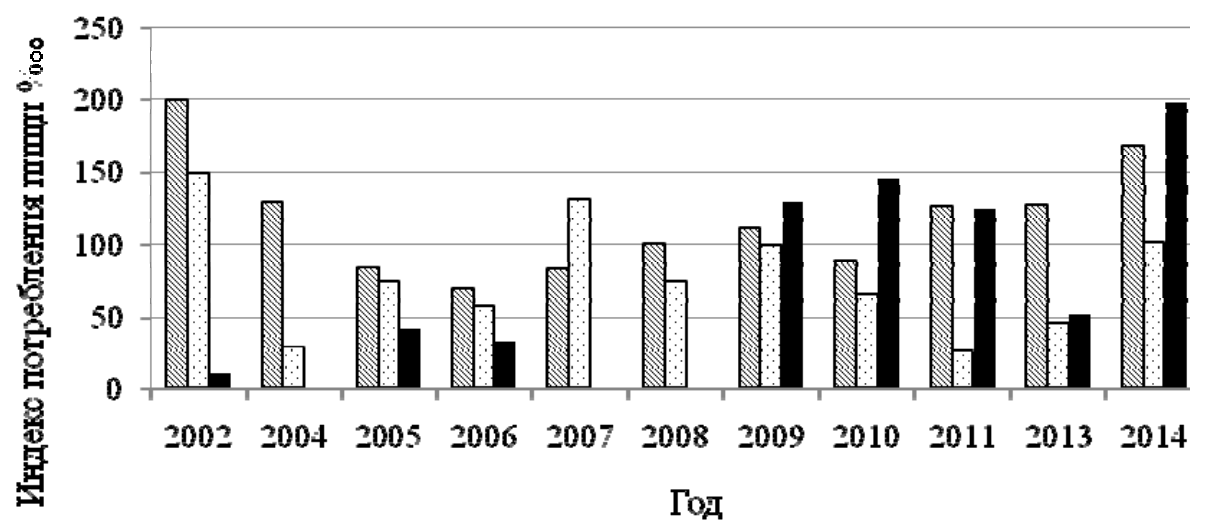

\$Blemuiidae $\square$ Gobiidae Engraulidae.Carangidae. Sparidae. Mullidae

Рис. 2. Средний индекс потребления пищи (\%о) у личинок рыб разных семейств в устьевой части Севастопольской бухты

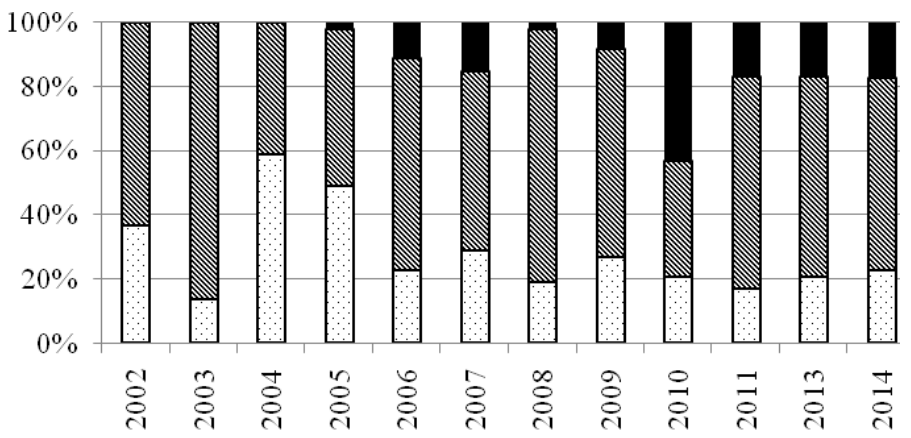

$\square$ Групша $2 \mathbb{\$}$ Групша $3 \quad$ Группа 4

Рис. 3. Процентное соотношение размерных групп личинок рыб на экзогенном питании в устьевой части Севастопольской бухты: группа 2 - смешанный тип питания; группа 3 - внешний тип питания; группа 4 - личинки, питающиеся взрослыми формами зоопланктона

на внешний тип питания (рис. 3). В период с 2002 по 2009 г. этот показатель был низкий, и, как правило, в наших сборах присутствовали личинки, находящиеся на смешанном (группа 2) и внешнем (группа 3) типах питания. В некоторые годы личинки группы 4, питающиеся в большей степени взрослыми формами зоопланктона, вообще не были отмечены в наших сборах (рис. 3). В 2010 г. был зафиксирован самый высокий показатель данного параметра - 43 \%, в последующие годы доля личинок старшей возрастной группы была стабильной и практически одного порядка $(17-21 \%)$.

С 2010 г. в среднемесячных температурах воздуха отмечено значительное превышение климатической нормы в июне-августе. Температура на поверхности моря достигала $29,0{ }^{\circ} \mathrm{C}$ и была выше критической $\left(26^{\circ} \mathrm{C}\right)$, при которой уменьшалась плодовитость мнемиопсиса (Аболмасова и др., 2012). Все последующие годы не отличались друг от друга сезонным ходом температур. Поэтому сезонная динамика обилия и уровень коли- 
чественного развития гребневиков в этот период оказались сходными. В 1998-2013 гг. суммарная популяция мнемиопсиса ни разу не достигала размера конца 1980-х - середины 1990-х гг. (Shiganova et al., 2014; Stefonova, 2014).

В 2010 г. отмечена вспышка численности метазойного микрозоопланктона с максимумами в летний период - 250-530 тыс. экз/ $\mathrm{M}^{3}$ и среднегодовым значением более 140 тыс. экз $/ \mathrm{M}^{3}$ (Серегин, Попова, 2012). Эти показатели оставались непревзойденными в последующие 3 года. Они были превышены в 2014 г., когда в летний период в поверхностном слое устьевой части Севастопольской бухты отмечена рекордная за пятилетний срок наблюдений численность вселенца O. davisae, она временами превышала 1,25 млн экз $/ \mathrm{M}^{3}$. В это время в вертикальных ловах средняя численность личинок рыб возросла на порядок и составила 38 экз/ $\mathrm{M}^{2}$. В поверхностном горизонте моря максимальная численность личинок семейства Blenniidae превышала 2300 экз. на десятиминутный поверхностный лов, что в три раза выше, чем в 1960-1970-х гг. (Дехник, 1973). Это хорошо согласуется с высокими показателями развития метазойного микрозоопланктона кормовой базы личинок рыб.

Негативные изменения в любой экосистеме в связи с воздействием как природных, так и антропогенных факторов проявляются прежде всего в снижении видового разнообразия видов, ее населяющих (Одум, 1986). Динамика показателей индексов видового разнообразия и доминирования ихтиопланктона в устьевой части Севастопольской бухты в с 1990 по 2014 г. представлена на рис. 4. Если в период с 1990 по 2003 г. показатели индексов видового разнообразия колебались в пределах от 1,5 до 3,0, то начиная с 2004 г. - от 2,5 до 3,5. Форма кривых доминирования-разнообразия ихтиопланктона (рис. 5) в 1990 и 1994 гг. характерна для олиготрофных районов исследований с низкой численностью и небольшим количеством видов, ее обеспечивающих. Такая же картина наблюдается у сообществ, находящихся в состоянии стресса в результате негативного воздействия каких-либо биотических или абиотических факторов (Одум, 1986). Форма кривых доминированияразнообразия ихтиопланктона в период с 2009 по 2014 г. (рис. 5) близка к логнормальному распределению, которое характерно для сообществ с высокой видовой насыщенностью. Промежуточную форму имеет кривая доминирования-разнообразия, построенная по данным исследований 2004 г., когда наблюдался низкий индекс доминирования и высокий индекс видового разнообразия, однако численность ихтиопланктона в пробах была сравнительно низкой (рис. 4, 5).

С 2009 г. отмечалось снижение количества видов взрослых рыб в уловах, что сопровождалось одновременным увеличением численности отдельных теплолюбивых видов, в том числе промысловых видов - султанки Mullus barbatus ponticus Essipov, 1927 и ставриды Trachurus mediterraneus ponticus Aleev, 1956. Доля султанки в уловах донных ловушек в период с 2009 по 2014 г. колебалась от 30 до 40 \%, а в отдельные годы превышала $80 \%$ от общей численности всех видов. Увеличение численности султанки и ставриды в уловах, вероятнее всего, связано с улучшением условий обитания пелагических видов рыб и прежде всего с хорошей кормовой базой для взрослых рыб и их личинок. Это подтверждается увеличением доли личинок промысловых видов рыб в ихтиопланктоне, увеличением индекса потребления пищи и возрастанием доли личинок старших возрастных групп (рис. 2, 3). Можно отметить 


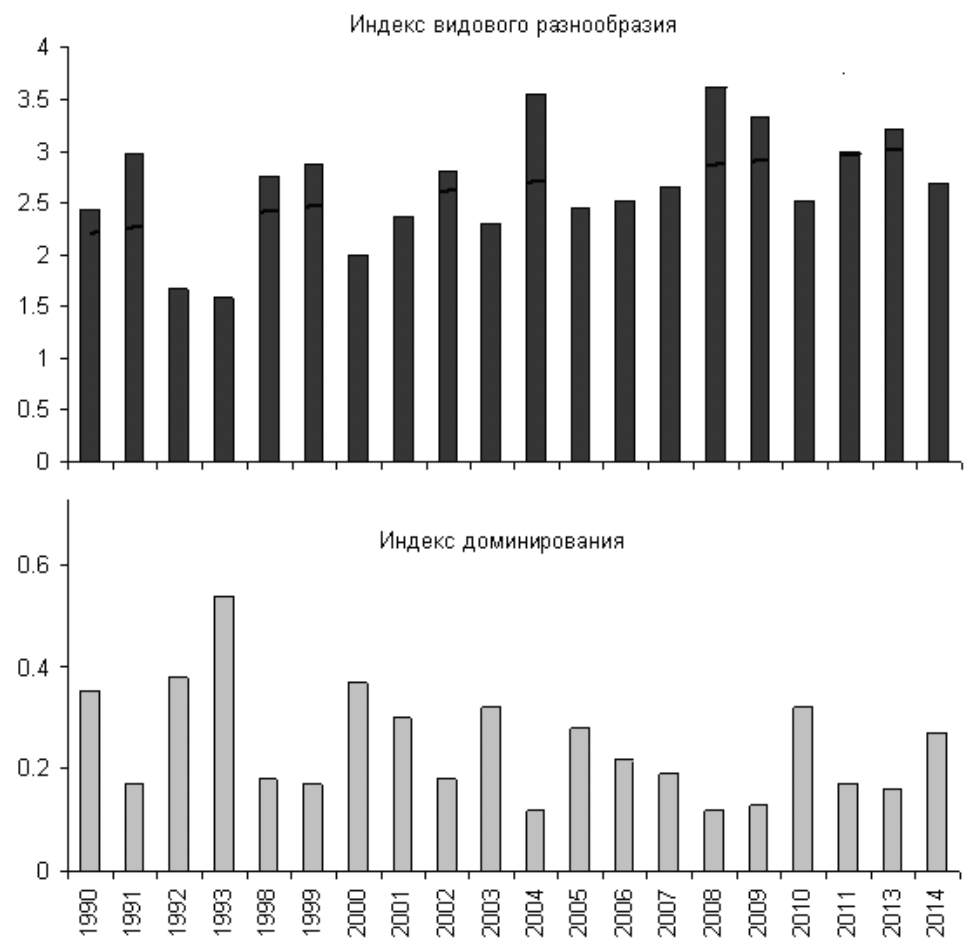

Рис. 4. Индексы видового разнообразия и доминирования ихтиопланктона в устьевой части Севастопольской бухты в 1990-2014 гг.

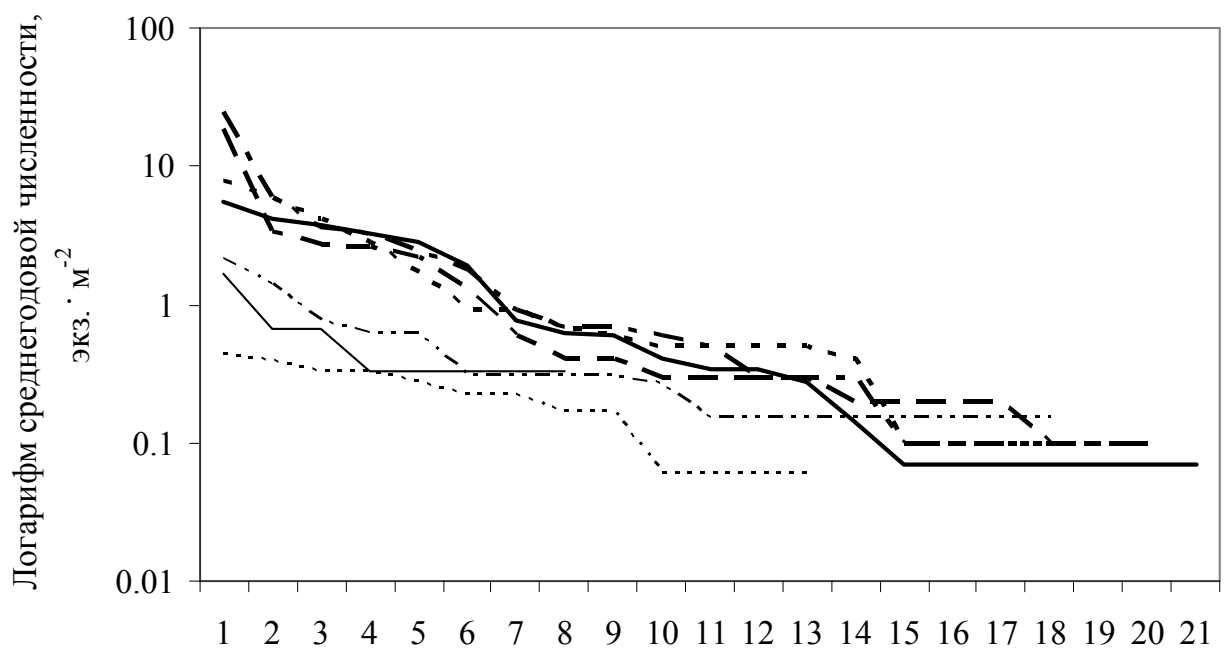

Ранжированный ряд видов в порядке доминирования

….. $1990-1994-\cdots-\cdots 2004-2009-2010-\cdots 13---2014$

Рис. 5. Кривые доминирования-разнообразия ихтиопланктона в устьевой части Севастопольской бухты в различные годы исследований 
увеличение численности личинок не только преобладающих в уловах взрослых рыб султанки и ставриды, но и хамсы, которая достаточно редко попадает в донные ловушки в связи с особенностями экологии и довольно крупной ячеей сети в донных ловушках. Хамса в теплый сезон года держится в верхнем квазиоднородном слое, а в зимний сезон, с понижением температуры поверхности моря ниже $7^{\circ} \mathrm{C}$, уходит из мелководных районов, к которым относится устьевая часть Севастопольской бухты, в глубоководные районы, где встречается на глубине 70-80 м (Световидов, 1964; Васильева, 2007).

\section{Заключение}

В 2002-2014 гг. по сравнению с 19891990 гг. индекс видового сходства взрослых рыб с ихтиопланктоном возрос в 1,5 раза.
Форма кривых доминирования-разнообразия ихтиопланктона с 2009 по 2014 г. близка к логнормальному распределению, которое характерно для сообществ с высокой видовой насыщенностью. Возросшая численность мелкого рачкового зоопланктона, в том числе вселенца Oithona davisae, способствовала не только увеличению численности и выживанию личинок рыб, но и постепенному восстановлению их видовой структуры. Об этом свидетельствует увеличение доли личинок промысловых видов-мигрантов в ихтиопланктонных сборах, высокие показатели индекса потребления пищи, увеличение количества потребленных пищевых объектов в кишечниках личинок рыб, отсутствие в наших сборах с 2006 г. личинок с пустыми кишечниками и стабильно высокие показатели доли личинок старших возрастных групп.

\section{Список литературы}

Аболмасова Г.И., Финенко Г.А., Романова 3.А., Дацык Н.А., Аннинский Б.Е. (2012) Состояние желетелого макрозоопланктона в шельфовой зоне крымского побережья Чёрного моря в 2009-2010 гг. Морской экологический журнал, 11 (3): 17-24 [Abolmasova G.I., Finenko G.A., Romanova Z.A., Datsik N.A., Anninsky B.E. (2012) State of gelatinous macrozooplankton in the shelf zone of the Crimean Black Sea coast in 2009-2010. Marine Ecological Journal [Morskoi ecologicheskii zhurnal], 11 (3): 17-24 (in Russian)]

Акватория и берега Севастополя: экосистемные процессы и услуги обществу (1999) Павлова Е.В., Шадрин Н.В. (ред.) Севастополь, Аквавита, 289 с. [The waters and the coast of Sevastopol: ecosystem processes and services to the public (1999) Pavlova E.V., Shadrin N.V. (eds.) Sevastopol, Aquavita, 289 p. (in Russian)]

Болтачев А.Р., Карпова Е.П. (2012) Ихтиофауна прибрежной зоны Севастополя (Черное море). Морской экологический журнал, 11 (2): 10-26 [Boltachev A.R., Karpova E.P. (2012) Ichthyofauna of the coastal area of Sevastopol (the Black Sea). Marine Ecological Journal [Morskoi ecologicheskii zhurnal], 11 (2): 10-26 (in Russian)]

Васильева Е.Д. (2007) Рыбы Черного моря. М., ВНИРО, 239 с. [Vasilyeva E.D. (2007) Fishes of the Black Sea. M., VNIRO, 239 p. (in Russian)]

Водяницкий В.А. (1936) Наблюдения над пелагическими яйцами рыб Черного моря. Tpyды Севастопольской биологической станичии, 5: 3-14 [Vodyanitsky V.A. (1936) Observations on pelagic fish eggs of the Black Sea. Proceedings of the Sevastopol Biological Station [Trudy sevastopolskoi biologicheskoi stancii], 5: 3-14 (in Russian)] 
Гордина А.Д., Ткач А.В., Павлова Е.В., Климова Т.Н., Овсяный Е.И., Романов А.С., Репетин Л.М. (2003) Состояние ихтиопланктонных сообществ в Севастопольской бухте (Крым) в маесентябре 1998-1999 гг. Вопросы ихтиологии, 43 (2): 184-193 [Gordina A.D., Tkach A.V., Pavlova E.V., Klimova T.N., Ovsynuy E.I., Romanov A.S., Repetin L.M. (2003) State of ichthyoplankton communities in the Sevastopol Bay (Crimea) in May-September 1998-1999. Journal of Ichthyology [Voprosy Ikhtiologii], 43 (2): 184-193 (in Russian)]

Дехник Т.В. (1971) Особенности строения, развития и экологии пелагических икринок и личинок рыб Черного моря. Биология моря, 25: 3-29 [Dehnik T.V. (1971) Features of the structure, development and ecology of pelagic fish eggs and larvae in the Black Sea. Russian Journal of Marine Biology [Biologia Morya], 25: 3-29 (in Russian)]

Дехник Т.В. (1973) Ихтиопланктон Черного моря. Киев, Наукова думка, 234 с. [Dekhnik T.V. (1973) Ichthyoplankton of the Black Sea. Kiev, Naukova dumka, 234 p. (in Russian)]

Дука Л.А. (1959) О нересте рыб в Севастопольской бухте. Труды Севастопольской биологической станции, 2: 189-200 [Duka L.A. (1959) About spawning of fishes in the Sevastopol bay. Proceedings of the Sevastopol Biological Station [Trudy sevastopolskoi biologicheskoi stancii], 2: 189200 (in Russian)]

Дука Л.А., Синюкова В.И. (1976) Руководство по изучению питания личинок и мальков морских рыб в естественных и экспериментальных условиях. Киев, Наукова думка, 110 с. [Duka L.A., Sinyukova V.I. (1976) A manual for the study of the nutrition of marine fishes larvae and juveniles under natural and experimental conditions. Kiev, Naukova dumka, 110 p. (in Russian)]

Зайцев Ю.П. (1992) Экологическое состояние шельфовой зоны Черного моря у побережья Украины (обзор). Гидробиологический журнал, 28 (4): 3-18 [Zaytsev Y.P. (1992) Ecological status of the shelf zone of the Black Sea coast of Ukraine (review). Hydrobiological Journal [Gidrobiologicheskii Zhurnal], 28 (4): 3-18 (in Russian)]

Замбриборщ Ф.С. (1985) О современных тенденциях изменений черноморских ихтиоценозов. Вопросы ихтиологии, 25 (4): 699-690 [Zambriborsch F.S. (1985) Current trends in changes of the Black Sea ichthyocenoses. Journal of Ichthyology [Voprosy Ikhtiologii], 25 (4): 699-690 (in Russian)]

Зернов С.А. (1913) К вопросу об изучении жизни Черного моря. СПб: Записки Императорской Академии наук, 32 (1): 99 [Zernov S.A. (1913) On the question of studying of life in the Black Sea. St. Petersburg: Notes of the Imperial Academy of Sciences [Zapiski Imperatorskoi Academii Nauk], 32 (1): 99 (in Russian)]

Золотарев П.Н. (1994) Структура биоценозов бентали северо-западной части Черного моря и ее трансформация под воздействием антропогенных факторов: автореф. дис. ... канд. биол. наук: 03.00.17. Севастополь, 20 c. [Zolotarev P.N. (1994) The structure of the benthic biocenoses in the north-western part of the Black Sea and its transformation under influence of anthropogenic factors. Abstract of PhD thesis in Biology: 03.00.17. Sevastopol, 20 p. (in Russian)]

Игнатьев С.М., Зуев Г.В., Мельникова Е.Б. (2001) Многолетняя динамика состояния популяции гребневика Mnemiopsis leidyi Agassiz в районе Севастополя (Черное море). Экология моря, 56: 8-12 [Ignatyev S.M., Zuev G.V., Melnikova E.B. (2001) Long-term dynamics of population of Mnemiopsis leidyi Agassiz near Sevastopol (the Black Sea). Ecology of the Sea [Ecologia morya], 56: 8-12 (in Russian)] 
Ихтиофауна черноморских бухт в условиях антропогенного воздействия (1993) Овен Л.С. (ред.) Киев, Наукова думка, 143 с. [Ichthyofauna of the Black Sea bays under human impact (1993) Oven L.S. (ed.) Kiev, Naukova dumka, 143 p. (in Russian)]

Климова Т.Н. (2005) Ихтиопланктон Черного моря как индикатор экологического состояния шельфовых вод Украины:: автореф. дисс... канд. биол. наук: 03.00.10. Москва, 25 с. [Klimova T.N. (2005) Ihtyoplankton of the Black Sea as an indicator of the ecological state of the Ukrainian shelf waters. Abstract of PhD thesis in Biology: 03.00.10. Moscow, 25 p. (in Russian)]

Климова Т.Н., Вдодович И.В. (2011) Численность, видовое разнообразие ихтиопланктона и особенности питания личинок рыб в прибрежной акватории юго-западного Крыма в 20002009 гг. Промысловые биоресурсы Черного и Азовского морей. Еремеев В.Н. (ред.) Севастополь, ИнБЮМ НАНУ, с. 101-116 [Klimova T.N., Vdodovich I.V. (2011) Abundance, diversity of ichthyoplankton and feeding habits of fish larvae in the coastal waters of southwest Crimea in 20002009. Commercial bioresources of the Black and Azov Seas. Eremeev V.N. (ed.) Sevastopol, IBSS NASU, p. 101-116 (in Russian)]

Куфтаркова Е.А., Субботин А.А., Родионова Н.Ю., Иванов В.Н. (2007) Экологические условия выращивания мидий в Севастопольской бухте. Экологическая безопасность прибрежных и шельфовых зон и комплексное использование ресурсов шельфа, 15: 110-119 [Kuftarkova E.A., Subbotin A.A., Rodionova N.U., Ivanov V.N. (2007) Ecological conditions of mussel cultivation in the Sevastopol bay. Ecological safety of coastal and shelf zones and complex use of shelf resources [Ecolgicheskaya bezopasnost pribrezhnoy i shelfovoi zon i kompeksnoey ispozovanie resursov shelfa], 15: 110-119 (in Russian)]

Одум Ю. (1986) Экология. T. 2. М., Мир, 373 с. [Odum J. (1986) Ecology. Vol. 2. Moscow, Mir, 373 p. (in Russian)]

Определитель фауны Черного и Азовского морей (1969) Т. 2. Водяницкий В.А. (ред.) Киев, Наукова думка, 535 с. [Key to the fauna of the Black and Azov Seas (1969) V 2. Vodjnitcky V.A. (ed.) Kiev, Naukova dumka, 535 p. (in Russian)]

Петипа Т.С. (1957) О среднем весе основных форм зоопланктона Черного моря. Tpyды Ceвастопольской биологической станции, 9: 39-57 [Petipa T.S. (1957) Average weight of the main forms of zooplankton of the Black Sea. Proceedings of the Sevastopol Biological Station [Trudy sevastopolskoi biologicheskoi stancii], 9: 39-57 (in Russian)]

Правдин Н.Ф. (1966) Руководство по изучению рыб (преимущественно пресноводных). М., Пищевая промышленность, 267 с. [Pravdin N.F. (1966) Guide for fish study (mostly freshwater). Moscow, Food industry, 267 p. (in Russian)]

Размножение и экология массовых рыб Черного моря на ранних стадиях развития (1970) Водяницкий В.А. (ред.) Киев, Наукова думка, 211 с. [Reproduction and ecology of dominant fishes of the Black sea in the early stages of development (1970) Vodjnitcky V.A. (ed.) Kiev, Naukova dumka, 211 p. (in Russian)]

Расс T.C. (2001) Регион Черного моря и его продуктивность. Вопросы ихтиологии, 41 (6): 742-749 [Russ T.S. (2001) Black Sea region and its productivity. Journal of Ichthyology [Voprosy Ikhtiologii], 41 (6): $742-749$ (in Russian)]

Салехова Л.П., Гордина А.Д., Климова Т.Н. (2007) Ихтиофауна прибрежных вод югозападного Крыма в 2003-2004 гг. Вопросы ихтиологии, 47 (2): 173-187 [Salekhova L.P., Gordina 
A.D., Klimova T.N. (2007) Ichthyofauna of the south-western Crimean coastal waters in 2003-2004. Journal of Ichthyology [Voprosy Ikhtiologii], 47 (2): 173-187 (in Russian)]

Световидов А.Н. (1964) Рыббы Черного моря. М., Наука, 551 с. [Svetovidov A.N. (1964) Fish of the Black Sea. Moscow, Nauka, 551 p. (in Russian)]

Серегин С.А., Попова Е.В. (2012) Численность и видовой состав метазойного микрозоопланктона в прибрежье Севастополя: 2009-2012. Рыбное хозяйство Украины, 6: 3-9 [Seregin S.A., Popova E.V. (2012) Abundance and species composition of coastal microzooplankton near Sevastopol: 2009-2012. Fisheries of Ukraine [Rybnoye khozaistvo Ukraini], 6: 3-9 (in Russian)]

Финенко Г.А., Романова 3.А., Аболмасова Г.И., Аннинский Б.Е. (2006) Гребневикивселенцы и их роль в трофодинамике планктонного сообщества в прибрежных районах Черного моря (Севастопольская бухта). Океанология, 46 (4): 507-517 [Finenko G.A., Romanova Z.A., Abolmasova G.I., Anninsky B.E. (2006) Invasive ctenophore and their influence on trophodynamics of plankton community in the coastal areas of the Black Sea (Sevastopol bay). Oceanology [Okeanologia], 46 (4): 507-517 (in Russian)]

Gucu A.C. (2002) Can overfishing be responsible for the successful establishment of Mnemiopsis leidyi in the Black Sea? Estuarine, Coastal and Shelf Science, 54: 439-451

Shiganova T.A., Bulgakova Yu.V., Volovik S.P., Mirzoyan Z.A., Dudkin S.I. (2001) The new invader Beroe ovata Mayer 1912 and its effect on the ecosystem in the northeastern Black Sea. Hydrobiologia, 451: 187-197

Shiganova T.A., Molinero J., Sommer U., Javidpour J., Matej A., Christou E., Marambio M., Fuetes V., Mirseyan Z.A., Gulsahin N., Lombard F., Lilley M.K.S., Angtl D.L. (2014) Adaptive strategy of the invader Mnemiopsis leidyi and its predators Beroe spp. in Eurasian seas. Report of the Joint CIESM/ ICES Workshop of Mnemiopsis Science. Corunna, Spain, p. 4-11

Stefonova K. (2014) Mnemiopsis leidyi distribution and biomass index as an indicator of Good Environmental Status (GEnS) in Bulgarian waters. Report of the Joint CIESM/ICES Workshop of Mnemiopsis Science. Corunna, Spain, p. 35-139 